\title{
Interview of Eugenie C. Scott, Executive Director, National Center for Science Education. Interview conducted by Mick Wycoff
}

\author{
Mick Wycoff
}

Published online: 20 November 2007

(C) Springer Science + Business Media, LLC 2007

1. We see that you joined NCSE as Executive Director in 1987. What can you tell us about the early history of NCES and of your history there?

The early history of NCSE, as far as I am concerned, was pretty hectic "on-the-job training". I was hired because I had good communication skills, and because I knew the creationism and evolution controversy, and also because, with the Ph.D., I had the academic credibility to deal with the base of our membership, which is college-level scientists. But I didn't know anything about running a small business, I didn't know anything about nonprofit accounting, I didn't know anything about payrolls, I didn't know anything about the IRS regulations governing nonprofits, I didn't know anything about fundraising - you name it, I didn’t know it. But I learned.

We started out with me as the first employee, and I fairly quickly hired a part-time secretary. Next came a part-time bookkeeper and we gradually added more staff after that. Our two periods of major staff expansion were right after the 1999-2000 Kansas school board debacle, when donations went up, and recently after the Kitzmiller versus Dover trial. I was very pleased at the end of last year to hire my first two "specialists" staff: an education person, and a faith outreach person. Although all NCSE staff work on putting out "flareups" (helping local people to solve problems involving the teaching of evolution or the introduction of creationism), these two staff members' duties will, we hope, contribute to putting the brush fires out, rather than just handing out the fire extinguishers.

2. Looking back over your 20 years' service at NCSE, do you feel any sense of "plus ca change, plus c'est la

\footnotetext{
M. Wycoff $(\triangle)$

Public Television Station WLIW21,

New York City, NY, USA

e-mail: mick@NilesEldredge.com
}

meme chose" regarding the creationist challenge? Do you have a sense that creationism waxes and wanes?

The creationism/evolution controversy waxes and wanes depending on how much evolution is actually being taught, as reflected in curriculum and in textbooks. When there is little evolution being taught, the creationists don't bother us very much. When the amount of evolution goes up, the creationists swing into action. The fact that we have so much anti-evolutionism today is partly because evolution is in the science standards, and is therefore in the textbooks, and in the curricula of local districts. The "No Child Left Behind" requirement that students be tested in science beginning in 2007 has meant that for the last several years, every time that a state's science education standards come up for review, there's a big fight over the inclusion of evolution. Creationists know that if evolution is in the standards, it's going to be in the tests, and therefore it's going to be taught. The best way to keep your kid from learning evolution is to be sure that evolution is kept out of the science standards, or is presented as something to be "critically analyzed" (in other words, taught as if it were not valid science). So we've actually had more anti-evolutionism recently than 20 years ago.

3. Of course, you take an official position as a leader at NCSE, but could you share any of your more personal feelings about people like, say, Henry Morris?

Henry M. Morris was unquestionably the most important creationist of the 20th century. I only met him in person once, but we had a very cordial conversation. It was clear that we were not going to see eye-to-eye on the science, but we treated one another with respect. I took the opportunity to try to help him understand that although I am not a believer in God, I am not anti-religious. This is a difficult thing for many fundamentalists (and many atheists, for all 
of that) to understand. Like many conservative Christians, I found him personally to be a very caring individual. But clearly, his understanding of science did not reflect that of the mainstream, to put it mildly.

4. And what are your feelings abut Dawkins, Dennett, and other scientists busy fulminating about atheism?

I have friendly relationships with both Richard Dawkins and Daniel Dennett, although I know Richard better than Dan. Richard's goal is to persuade people to give up religious faith, which he considers an injurious superstition, and become freethinkers, preferably freethinkers with great respect for science. My goal is to get people to understand science as a way of knowing, and to accept evolution as a major-and valid-scientific concept. It has been my experience that one cannot work for both of these goals simultaneously, at least not in the United States. In our country, something like $85 \%$ or more of the population believes in God. If you make people choose between God and evolution, clearly, we are not going to have very many people who accept evolution. And, of course, it simply is a false dichotomy in the first place: although some Christian views, like biblical literalism, are incompatible with evolution, there are many Christian views, if not the majority, which accept evolution as compatible with Christian faith.

5. Politically, the nation is emerging from a period of ascendancy for the Christian right, with the residual sway of a right-leaning Supreme Court. Looking forward, how do you think these influences are likely to play out when it comes to science education, especially evolution?

It will take a long time to recover from the large number of district court and appeals court judges nominated by the current administration. Analyses have shown that the Bush appointees are disproportionately conservative, and in general, have little respect for the establishment clause of the First Amendment. And I would not rule out the Christian right as a political force. They may not be effective at the national level, but they have deliberately targeted local offices like school boards, city councils, county boards, and the like and continue to be a strong political movement.

6. We congratulate you on the publication of your recent book, Not in Our Classrooms, written with your colleague Glenn Branch. How is it doing, and what are you up to now, besides your continuing work for NCSE?

Thank you. Although this book began as a planned collaboration, Glenn really ended up doing the vast majority of the work on it. I think it's a very good collection of articles, but Glenn gets the credit for having done the huge majority of working with the authors to produce very good selections. It's doing rather well I think. Because it's short, and inexpensive, people can use it for a quick introduction to the intelligent design issue, and then if still wanting more, can use the references within it to guide them to additional study. Right now, I'm revising my book Evolution Versus Creationism for a second edition, and unfortunately, am way behind! I wish I were a faster writer. We also are concerned about a number of "flareups" around the country, perhaps most important of which being a decision by the Texas Board of Education to move up the revision of the Texas standards from 2008 to 2007. Doubtless, the fact that there is now a conservative majority on the school board is merely a coincidence.... We anticipate a fight over the revision of the standards to either downplay evolution, or require that evolution be qualified in some serious way, perhaps using the "strengths and weaknesses", or "evidence against evolution", or "critical analysis" language that we've seen in other states. If this kind of wording goes into the Texas standards, textbook publishers will have to revise their biology textbooks to reflect this kind of bad science. And, because of the influence of Texas on the national textbook market, there could be negative repercussions across the board.

7. After devoting the majority of your adult life to fighting creationism, do you feel there has been any progress?

Heck yes! If NCSE hadn't been here, the situation would be a whole lot worse than it is now! But seriously, this is not a controversy that's going to be solved merely by throwing science at it. The creationism/evolution controversy is a multifactorial problem, and it will require multifactorial solutions. Science is necessary but not sufficient: we need not only better science education at the high school level, but at the college level, where the high school teachers are trained. We need more input from the mainstream faith community to inform their members that evolution is acceptable to their theological traditions. And all of us on the evolution side of this issue need to learn how to better communicate evolution and the nature of science to not only our students, but to reporters, and the general public. There is a huge amount of confusion about evolution out there, and it is fed daily by a massive creationist propaganda mill. The intelligent design proponents are particularly good at this.

8. Is there any difference between the two creationist approaches to evolution called creation science and intelligent design?

Creation science is a religious movement that began back in the 1960 s that attempts to promote Christianity by 
claiming that a biblical literalist interpretation of Genesis can be supported through science. ID is a more recent movement that conceals its promotion of Christianity more carefully. The public focus of ID reflects William Paley's design argument where great biological complexity (such as the bacterial flagellum, or the immune system) is declared impossible of explanation through evolution. This leaves a place for special creation by the unnamed "intelligent designer", or Designer. The history of intelligent design (ID) clearly roots it in the earlier movement of creation science. My colleague Nick Matzke and I recently detailed this in an article (http://www.pnas.org/cgi/reprint/104/ suppl_1/8669.pdf). In content, ID is a subset of creation science, ignoring many arguments of the latter such as Noah's flood as the source of the geological column and a 10,000-year-old Earth, but recycling other creationist standards. Everything expressed in ID had its precurser in creation science, including doubts about the power of natural selection, and even the "information theory" handwaving. One difference between them is that ID is a lot smaller movement that has been much more successful in attracting the notice of the mainstream press. Their star seems to be fading a bit these days, though, as they have failed to produce the often-promised scientific discoveries that are always "just around the corner". The press is beginning to catch up with scientists in understanding that ID is so much vapor ware.

9. Now that the courts have outlawed teaching creation science in science classes, do you think creationism has hit the wall when it comes to attacks on teaching evolution in science classes, or do you predict they will come up with further arguments?

When the Supreme court declared teaching creation science unconstitutional, creation science did not go away. It in fact has prospered and even grown. In May 2007, Answers in Genesis - which didn't even exist at the time of the 1987 Supreme Court decision against creationism opened a 60,000-ft-sq. state-of-the-art museum complete with animatronic dinosaurs and people-in the same dioramas. (I especially liked the baby Triceratops wearing a saddle.) The failure of creation science begat intelligent design, and although a Federal District court has declared
ID unconstitutional, this won't be the end of ID anymore than the court rejection ended creation science. There will likely be a new agent-less form of creationism (perhaps "sudden emergence theory" - if it doesn't cause people to fall on the floor laughing too hard), and we already have been dealing with the current best hope of antievolutionists: the "critical analysis of evolution" strategy. This is a variant of the fairness ("let's teach both and be fair") approach that has been so effective for creationists in American culture, but it stresses the pedagogical value of giving students "all the evidence" to improve their critical thinking skills. Of course, having students think critically is important, but they should be thinking critically about issues that are actually in contention, not made-up controversies like whether living things had common ancestors. I wrote an article on this for the McGill Journal of Education (Scott, E. C. [in press] What's wrong with the "teach the controversy" slogan? McGill Journal of Education.) The biggest problem, though, is teachers who decide that they don't want to teach evolution because they fear they will be challenged on it. And the even bigger problem is administrators who (1) let them get away with it and (2) don't back up the teachers who are challenged.

10. What are the most hopeful signs you can point to in the continuing struggle to conquer creationism?

That the scientific community has become more active and more aware that this is a problem that they have a responsibility to address. Minimally, a university-level scientist can do a better job presenting evolution to his or her students: we have a long way to go in this regard. But academics also need to pay attention to what's going on in their local communities regarding who is running for school boards and what their positions are. There is a small but I think growing realization among academics that they can contribute a lot to the solution of this problem by standing for election for local school boards - although I know this is not for everyone. I also see science education organizations like NABT and NSTA having more workshops on how to teach evolution better. After the Kitzmiller versus Dover trial, the press seems to understand that intelligent design is really just another version of creationismalthough there are occasional articles that present the possibility that ID is valid science. 